\title{
Association between Emotional Intelligence and Academic Self-Efficacy of Preservice Primary Teachers
}

\author{
DOI: 10.26466/opus.837349
}

\author{
* \\ Askın Baydar* \\ * Dr. Öğr. Üyesi, Artvin Çoruh Üniversitesi/Eğitim Fakültesi, Artvin/Türkiye \\ E-Mail: askinbaydar@artvin.edu.tr \\ ORCID: $\quad$ 0000-0002-5795-8282
}

\begin{abstract}
In this study, the association between emotional intelligence levels and academic self-efficacy was investigated for preservice primary teachers in the education faculty. A total of 60 preservice teachers, 43 women and 17 men, participated in this research which used the relational screening model. As data collection measures, the Emotional Intelligence and Academic Self-Efficacy scales were used. The Emotional Intelligence Scale is a 20-item, Likert-type scale developed by Hyuneung Lee and Yungjung Kwak and adapted to Turkish by Şehri Nur Kayihan and Serhat Arslan. It comprises the subdimensions of emotional recognition, emotional facilitation and emotional regulation. The College Academic Self-Efficacy Scale is a Likert-type scale with 33 items developed by Owen and Robin Froman and adapted to Turkish by Gülay Ekici. It consists of three subdimensions of social status, cognitive applications and technical skills. The results of the research show that there were no differences in emotional intelligence and academic self-efficacy total points and subdimensions according to the gender variable. Emotional intelligence total points were understood to positively and significantly affect academic self-efficacy total points. The subdimension of emotional recognition predicted academic self-efficacy at significant levels.
\end{abstract}

Keywords: Emotional intelligence, academic self-efficacy, primary education, teacher education 
ISSN: 2528-9527

E-ISSN : 2528-9535

YIl Year: 11

Cilt Volume: 17

Sayı Issue:36

Nisan April 2021

Makalenin Gelis Tarihi Received Date. 08/12/2020

Makalenin Kabul Tarihi Accepted Date. 06/04/2021

\section{Sınıf Öğretmeni Adaylarının Duygusal Zekâları ve Akademik Öz Yeterlikleri Arasındaki İlişkiler}

\section{Öz}

Bu çalışmada eğitim fakültesi sını eğitimi öğretmen adaylarının duygusal zekâ düzeyleri ile akademik öz yeterlikleri arasındaki ilişki incelenmiştir. 43 kadın, 17 erkek, toplam 60 öğretmen adayının katıldığ araştırma ilişkisel tarama modeli ile gerçekleştirilmiştir. Araştırmada veri toplama aracı olarak Duygusal Zekâ ve Akademik Öz Yeterlik ölçekleri kullanılmıştır. Duygusal Zekâ ölçeği, Hyuneung Lee ve Yungjung Kwak tarafindan geliştirilen ve Şehri Nur Kayıhan ve Serhat Arslan tarafindan Türkçe'ye uyarlanan, 20 maddeden oluşan, likert tipi bir ölçektir. Duygusal farkındalık, duygusal kolaylaştırma ve duygusal düzenleme alt boyutlarından oluşmaktadır. Akademik Öz Yeterli Ölçeği ise Steven Owen ve Robin Froman tarafindan geliştirilen ve Gülay Ekici tarafindan Türkçe'ye uyarlanan 33 maddeden oluşan likert tipi ölçektir. Sosyal statü, bilişsel uygulamalar ve teknik beceriler olmak üzere üç alt boyuttan oluşmaktadır. Araştırmanın sonucunda cinsiyet değişkenine göre duygusal zekâ ve akademik öz yeterlik toplam ve alt boyutları arasında anlamlı farklıliklar meydana gelmemiştir. Duygusal zekâ toplam puanlarının, akademik öz yeterlik toplam puanların olumlu ve anlamlı yönde etkilediğ i anlaşılmıştır. Alt boyutlardan duygusal farkındalık, akademik öz yeterliği anlaml düzeyde yordamaktadır.

Anahtar Kelimeler: Duygusal zekâ, akademik öz yeterlik, sinff eğitimi, öğretmen eğitimi 


\section{Introduction}

Self-efficacy beliefs are defined as a person's perception of control over their own movements, just as in relation to their ability to successfully complete a task (Hoigaard, Kovac, Overby, and Haugen, 2015). Academic self-efficacy is related to opinions about being able to successfully complete an academic task at the level designed by the individual (Schunk, 1991). According to Bandura (1997), there are four sources of academic self-efficacy; mastery experience, vicarious experience, social persuasion, and physiological state. These sources of self-efficacy affect the academic self-efficacy of students and their success in class. When compared with students who are suspicious about their own learning abilities, students who feel adequate to complete learning or homework will participate without difficulty, work harder, be more resilient in the face of difficulties and be more successful (Schunk and Pajares, 2002). If an individual has strong self-efficacy related to a certain task or aim, they will be resilient about overcoming any obstacles which emerge (Lane, Lane, and Kyprianou, 2004). According to Eakman, Kinney, Schierl and Henry (2019), as academic self-efficacy levels increase, academic problems reduce.

Academic self-efficacy affects the beliefs and attitudes of teachers which determine teaching, thinking and decision-making (Manzar-Abbas, Khurshid, and Rizvi, 2018). Teachers who believe in their efficacy in relation to teaching spend more time on academic activities and may be more helpful to students in overcoming difficulties (Bandura, 1997). Teachers with high self-efficacy are more effective in class and more confident in themselves (Gibson and Dembo, 1984). Research related to the importance or effects on education of academic self-efficacy in teachers has obtained interesting results. Taşdemir (2019) found that preservice primary education mathematics teachers had high perceptions of academic self-efficacy, while according to Pehlevan, Muştu and Çepikkurt (2017) there is a negative correlation between the occupational anxiety and academic self-efficacy of preservice teachers. Nasir and Iqbal (2019) found a significant positive association between the academic success levels of preservice teachers with academic self-efficacy. According to the results of research about university students including preservice teachers by Çelik, Orçan and Altun (2000), academic self-efficacy was directly affected by life satisfaction. Titrek, Çetin, 
Kaymak and Kaşıkçı (2018) concluded there was a positive association between academic self-efficacy and motivation of preservice teachers and that the academic self-efficacy of preservice teachers was at the desired levels.

One of the factors which has significant level of interaction with academic self-efficacy is emotional intelligence. According to Mayer, Salovey and Carusto (2008), emotional intelligence is the ability of a person to understand their own feelings and other people's feelings, to manage them and to provide appropriate reactions to these feelings. There are four skills which comprise emotional intelligence according to Mayer, Caruso and Salovey (1999); perception of feelings, use of feelings to facilitate thinking, understanding feelings and managing feelings. According to Goleman (1995), emotional intelligence is the capacity to recognize feelings in ourselves and others to motivate ourselves and to manage our emotions within ourselves and our relationships. It comprises personal (recognizing feelings, managing feelings, self-motivation) and social capabilities (recognizing feelings in others, maintaining relationships). When we examine the literature, we see that the association between emotional intelligence and academic self-efficacy is generally in a positive direction. Şenel and Tamer (2018) concluded that students with high emotional intelligence levels had increased academic self-efficacy beliefs as a result of their study of preservice teachers in physical education and sports teaching, science teaching, mathematic teaching, social sciences teaching, music teaching and art teaching departments. In research investigating the relationship between emotional intelligence levels and academic self-efficacy of only physical education and sports preservice teachers by Türkekul and Sarıkabak (2019), similarly as emotional intelligence levels increased, academic self-efficacy levels were determined to increase. In studies performed with university students, emotional intelligence was a predictor of academic self-efficacy for clinical psychologic students according to Saeed and Ahmad (2000); for students from the engineering department mainly taking information processing lessons according to Belanger, Lewis, Kasper, Smith and Harrington (2007); and for undergraduate and postgraduate students from many departments according to Catalina, Stanescu and Mohorea (2012). Studies by Gharetepeh, Safari, Pashaei, Razaei, and Kajbaf (2015) and Ibrahim et al. (2017) of students in medical faculties showed a positive correlation between emotional intelligence and self-efficacy, while Sert and Traş (2019) 
and Kang and Oh (2015) identified a positive correlation between emotional intelligence levels and academic self-efficacy for students at high school level. And in this study, the association between emotional intelligence levels and academic self-efficacy of preservice primary teachers was investigated.

\section{Method}

This research was completed with the relational screening model.

\section{Participants}

The study group in the research comprised preservice teachers attending the third year of the primary education department in the education faculty of a state university in the fall semester of 2019-2020 academic year. The data were collected in November of 2019. Sixty students participated in the study. Of students, $71.7 \%$ were women and $28.3 \%$ were men.

\section{Data Collection Instruments}

Two scale tools were used as data collection measures in the research; the Emotional Intelligence and Academic Self-Efficacy scales.

Emotional Intelligence Scale: This was developed by Lee and Kwak (2012) and comprises 20 items. The scale uses a Likert-type evaluation system. The scale was understood to comprise three factors after factor analysis. These are F1 for items 1-6, F2 for items 7-12 and F3 for items 13-20. These factors are emotional recognition/understanding, emotional facilitation, and emotional regulation. The scale was adapted to Turkish by Kayıhan and Arslan (2016). Psychometric analyses of the scale appropriate to conditions in Turkey performed exploratory and confirmatory factor analysis, internal consistency coefficient and item analysis processes. The original three subscales of the test were confirmed with factor analysis performed in Turkey $\quad\left(x^{2}=399.55 ; \quad d f=167 ; \quad\right.$ RMSEA=.075; NNFI=.90; CFI=.91; IFI=.91; $\mathrm{SRMR}=.080 ; \mathrm{GFI}=.86$ ). The Cronbach alpha internal consistency coefficient for Turkey was found to be 83 .

College Academic Self-Efficacy Scale: This was developed by Owen and Froman (1988). It is a scale tool measuring self-confidence in basic skills like note-taking, answering questions, writing, adjustment to the basic pattern 
in class, and ability to use computers among students. It comprises 33 items and is a Likert-type scale. It has three subdimensions of social status, cognitive applications, and technical skills. The validity and reliability study for Turkey was completed by Ekici (2012). In this study the internal consistency coefficient was found to be .86 .

Responses to the scales were checked for accurate completion and scales that were not correctly completed were excluded. After this procedure, computer input was completed. Statistical analyses in the study were completed with the SPSS for Windows program. The Kolmogorov-Smirnov test was used to test the normality of the sample distribution. Later scales had descriptive statistical, Pearson correlation coefficients and finally regression analysis processes performed.

\section{Findings}

In the first stage of the research, the distribution of responses to the scales was investigated. With this aim, the Kolmogorov-Smirnov process was completed. For the emotional intelligence measure the statistical value was .107 and the significance level was .087. For the academic self-efficacy scale the statistical value was .087 and the significance level was.200. In line with this, it was understood that the distribution for both scales was normal. For this reason, the decision was made to use parametric statistical tests during the research. Table 1 presents the descriptive statistical values for the emotional intelligence and academic-self-efficacy scales.

Table 1. Descriptive statistics for emotional intelligence and academic self-efficacy measures

\begin{tabular}{llllll}
\hline Measures & $\mathbf{N}$ & Minimum & Maximum & Mean & Std. deviation \\
\hline Em. understanding & 60 & 2.67 & 5.00 & 3.9917 & .50648 \\
\hline Em. facilitation & 60 & 2.00 & 5.00 & 3.5889 & .65919 \\
\hline Em. regulation & 60 & 1.00 & 5.00 & 3.5521 & .83720 \\
\hline Emotional intelligence & 60 & 2.39 & 5.00 & 3.7109 & .52389 \\
\hline Social status & 60 & 1.40 & 4.50 & 3.1233 & .82202 \\
\hline Cognitive app. & 60 & 2.21 & 4.79 & 3.6211 & .60723 \\
\hline Technical skills & 60 & 2.00 & 5.00 & 3.7125 & .74194 \\
\hline Self-efficacy & 60 & 2.19 & 4.76 & 3.4156 & .62951 \\
\hline
\end{tabular}

The arithmetic mean for total points on the emotional intelligence scale was 3.17 and entered the 'I agree' interval of the Likert-type assessment. The 
arithmetic means for the emotional intelligence scale subdimension also entered the 'I agree' interval. The arithmetic mean of the total points on the academic self-efficacy scale was 3.41. This is within the 'I am undecided' assessment. The arithmetic means for the cognitive applications and technical skills subdimensions were 3.62 and 3.17 (I agree). The arithmetic mean for the social status subdimension was at lowest levels (arithmetic mean: 3.12). This entered the 'I am undecided' assessment, similar to the total academic self-efficacy points.

According to the gender variable, there were no significant differences between the emotional intelligence and academic self-efficacy total and subscale points.

The correlations between the totals and subdimensions of the two scales used within the scope of this research were found with the Pearson multiplication moments correlation coefficients and results are given in Table 2.

Table 2. Associations between total and subdimensions of emotional intelligence and academic self-efficacy measures

\begin{tabular}{lllll}
\hline N:60 Measure & Social status & Cognitive app. & Technical skills & Total academic self-efficacy \\
\hline Em. understanding & $.294\left(^{*}\right)$ & $.452\left(^{* * *}\right)$ & $.358\left(^{* *}\right)$ & $.414\left(^{* * *}\right)$ \\
\hline Em. facilitation & $.255\left(^{*}\right)$ & $.272\left(^{*}\right)$ & .167 & $.264\left(^{*}\right)$ \\
\hline Em. regulation & $.350\left(^{* *}\right)$ & .249 & $.262\left(^{*}\right)$ & $.335\left(^{* *}\right)$ \\
\hline Em. intelligence total & $.388\left(^{* *}\right)$ & $.392\left(^{(* *}\right)$ & $.325\left(^{*}\right)$ & $.423\left(^{* * *}\right)$ \\
\hline${ }^{*} \mathrm{P}<.05 \quad{ }^{* *} \mathrm{p}<.01 \quad{ }^{* * *} \mathrm{p}<.001$ & & &
\end{tabular}

There was a .423 positive correlation between the academic self-efficacy total and the emotional intelligence total. This result was significant from a statistical perspective at .001 . There were positive correlations between the emotional intelligence subdimensions of emotional recognition .414 $(\mathrm{p}<.001)$, emotional facilitation $.264(\mathrm{p}<.05)$ and emotional regulation .335 $(p<.01)$ with academic self-efficacy total points. There was a positive correlation between the academic self-efficacy subdimension of social status with the emotional intelligence total at $.388(\mathrm{p}<.01)$ level. There were correlations with cognitive applications at .392 ( $\mathrm{p}<.01)$ and technical skills at $.325(\mathrm{p}<.05)$. In the final stage of the research, regression analysis was performed to identify whether or not the independent variable of emotional intelligence predicted the dependent variable of academic self-efficacy. The results are presented in Table 3. 
Table 3. Regression analysis findings

\begin{tabular}{llll}
\hline Independent variable & $\mathbf{B}$ & $\mathbf{t}$ & $\mathbf{p}$ \\
\hline Fixed & 1.601 & 2.998 & .004 \\
\hline Emotional intelligence & .508 & 3.552 & .001 \\
\hline
\end{tabular}

R: .423 $\quad \mathrm{R}^{2} .179 \quad \mathrm{~F}: 12.618 \mathrm{p}<.001$

When the findings observed in Table 3 found as a result of regression analysis are investigated, the emotional intelligence total points of preservice teachers were understood to positively and significantly affect academic self-efficacy total points at .001 level. Emotional intelligence points explained $17.9 \%$ of the variance in academic self-efficacy points. The regression analysis results for the prediction of academic self-efficacy by emotional intelligence subdimensions are given in Table 4.

Table 4. Regression analysis findings

\begin{tabular}{llll}
\hline Independent variable & $\mathbf{B}$ & $\mathbf{t}$ & $\mathbf{p}$ \\
\hline Fixed & 1.045 & 1.601 & .015 \\
\hline Emotional understanding & .423 & 2.741 & .008 \\
\hline Emotional facilitation & .074 & .523 & .603 \\
\hline Emotional regulation & .138 & 1.208 & .232 \\
\hline
\end{tabular}

R: .472 $\quad \mathrm{R}^{2} .223 \quad \mathrm{~F}: 5.343 \quad \mathrm{p}<.003$

The regression analysis for the emotional intelligence scale subdimensions to predict the total academic self-efficacy points found the $\mathrm{R}$ value was .472 , with $\mathrm{R}^{2}$ value of .223 . This result shows that the emotional intelligence subdimensions in total explained $22.3 \%$ of the total variance in the academic self-efficacy total points. This result was significant and in a positive direction (F:5.343, $\mathrm{p}<.01$ ). When the " $\mathrm{t}$ " value is examined, only the emotional recognition subdimension was observed to be statistically significant among the subdimensions $(\mathrm{t}: 2.74 ; \mathrm{p}<.01)$. The other subdimensions did not predict self-efficacy points at significant level.

\section{Discussions and Conclusion}

In this study investigating the association between emotional intelligence levels and academic self-efficacy of preservice primary teachers, the first outcome found there were no significant differences between emotional intelligence and academic self-efficacy total and subdimension points according to the gender variable. In the relevant literature, there is no correlational 
study comparing emotional intelligence and academic self-efficacy variables in the context of gender. However, among studies of these two variables, research by Ibrahim et al. (2017) found that women received significantly better points then men for all dimensions of emotional intelligence. Research by Türkekul and Sarkabak (2019) with participation by preservice physical education and sports teachers obtained similar results; however, when academic self-efficacy points were compared according to gender, there were no statistically significant differences.

The second outcome in this study is the positive association between emotional intelligence and academic self-efficacy. This outcome is valid for all dimensions of the variables and is in parallel with the study by Kang and Oh (2015). This study was performed with participants at high school level and showed the presence of an association between emotional intelligence and academic self-efficacy not just at university level but also in the high school period when emotional and academic capabilities change rapidly. In the same way, Sert \& Traş (2019) concluded similar results in research with participants at high school level. According to the results of these studies, academic efficacy was found to have positive and significant level associations with all the subdimensions of emotional intelligence; in other words, intra-individual relationships, inter-individual relationships, adjustment skills, stress management, general mood and positive effect. Research at faculty level by Belanger et al. (2007), Gharetepeh et al. (2015) and Ibrahim et al. (2017) identified positive associations between emotional intelligence and self-efficacy levels, similar to this study.

Another result of this study is that among the emotional intelligence subdimensions measured in our study of emotional recognition, emotional facilitation and emotional regulation, only emotional recognition significantly predicted academic self-efficacy. This feature of the study partly overlaps with studies by Saaed and Ahmad (2000) who found all emotional intelligence subdimensions significantly predicted self-efficacy; and by Türkekul and Sarikabak (2019) who identified a positive, moderate-level association between the academic self-efficacy points of preservice teachers with optimism/mood regulation, and a positive low-level significant association between academic self-efficacy points with use of emotions, emotional assessment and emotional intelligence total points. The results found by Catalina, 
Stanescu, and Mohorea (2012) that the emotional intelligence subdimensions of emotional management and use of emotions were each weak predictors of academic self-efficacy shows similarity to the prediction levels of the final two dimensions of emotional intelligence in this study. Similarly, this study is partly confirmed by results from studies by Şenel and Tamer (2018) who found a weak positive association between the academic selfefficacy of preservice teachers with the emotional assessment subdimension of emotional intelligence, a moderate-level positive association with emotional management subdimension and a weak positive correlation with the empathic sensitivity subdimension. The negative correlation found with the positive use of emotions subdimension does not just contradict this study, but also other studies in the literature in general.

With these outcomes of the study, the emotional intelligence levels of students receiving teacher education and hence academic self-efficacies are at adequate levels. Preservice teachers who are aware of, can manage and regulate their own emotions will have upper level working habits, learning and success perceptions according to these results.

As seen in the literature, studies in this field are limited to participation by university and high school students. Studies to be performed with participants at lower educational levels will further expand this study area in the future. Additionally, future research is recommended about the effect on students in different departments of education faculties of activities to develop emotional intelligence. Also activities towards improving academic self-efficacy of preservice teachers should take place in curriculums of education faculties.

\section{Kaynakça / References}

Bandura, A. (1997). Self-efficacy: The exercise of control. Stanford University, CA:W.H. Freeman.

Belanger, F., Lewis, T., Kasper, G. M., Smith, W. J., and Harrington, K. V. (2007). Are computing students different? An analysis of coping strategies and emotional intelligence. IEEE Transactions on Education, 50(3), 188-196.

Catalina, C. C., Stanescu, D. F., and Mohorea, L. (2012). Academic self-efficacy, emotional intelligence and academic achievement of Romanian students. Results from an exploratory study. Journal of Educational Sciences and Psychology, 2(1), 41-51. 
Çelik, R., Orçan, F., and Altun, F. (2020). Investigating the relationship between life satisfaction and academic self-efficacy on college students' organizational identification. International Journal of Psychology and Educational Studies, 7(1), 76-85.

Eakman, A. M., Kinney, A. R., Schierl, M. L., and Henry, K. L. (2019). Academic performance in student service members/veterans: Effects of instructor autonomy support, academic self-efficacy and academic problems. Educational Psycho$\log y, 39(8), 1005-1026$.

Ekici, G. (2012). Academic self-efficacy scale: the study of adaptation to Turkish, validity and reliability. Hacettepe Üniversitesi Ĕgitim Fakültesi Dergisi-Hacettepe University Journal of Education, (43), 174-185.

Gharetepeh, A., Safari, Y., Pashaei, T., Razaei, M., and Kajbaf, M. B. (2015). Emotional intelligence as a predictor of self-efficacy among students with different levels of academic achievement at Kermanshah University of Medical Sciences. Journal of Advances in Medical Education \& Professionalism, 3(2), 50-55.

Goleman, D. (1995). Emotional intelligence: Why it can matter more than IQ. New York: Bantam Books.

Gibson, S., and Dembo, M. (1984). Teacher efficacy: A construct validation. Journal of Educational Psychology, 76, 569-582.

Hoigaard, R., Kovac, V. B., Overby, N. C., and Haugen, T. (2015). Academic self-efficacy mediates the effects of school psychological climate on academic achievement. School Pscyhology Quarterly, 30(1), 64-74. doi:10.1037/spq0000056

Ibrahim, N. K., Algethmi, W. A., Binshihon, S. M., Almahyawi, R. A., Alahmadi, R. F., and Baabdullah, M. Y. (2017). Predictors and correlations of emotional intelligence among medical students at King Abdulaziz University, Jeddah. Pakistan Journal of Medical Sciences, 33(5), 1080-1085.

Kang, Y. H., and Oh, E. J. (2015). Relationship among Emotional Intelligence, Academic Self-efficacy and Career Decision Level in High School Girls. Journal of the Korea Academia-Industrial cooperation Society, 16(8), 5152-5159.

Kayıhan, Ş. N., and Arslan, S. (2016). Duygusal Zeka Ölçeği: Bir Ölçek Uyarlama Çalışması. FSM İlmi Araştırmalar Insan ve Toplum Bilimleri Dergisi, (7), 137-145.

Lane, J., Lane, A. M., and Kyprianou, A. (2004). Self-efficacy, self esteem, and their impact on academic performance. Social Behavior and Personality: An International Journal, 32(3), 247-256. doi:10.2224/sbp.2004.32.3.247

Lee, H., and Kwak, Y. (2012). Development and initial validation of a trait emotional intelligence scale for Korean adults. Asia Pacific Education Review, 13(2), 209217. 
Manzar-Abbas, S., Khurshid, M. A., and Rizvi, S. A. A. (2018). Exploring differences among mentors' and mentees' self-efficacy beliefs at primary level education in China. New Horizons, 12(1), 23-40.

Mayer, J. D., Caruso, D. R., and Salovey, P. (1999). Emotional intelligence meets traditional standards for an intelligence. Intelligence, 27, 267-298.

Mayer, J. D., Salovey, P., and Caruso, D. R. (2008). Emotional intelligence: New ability or eclectic traits? American Psychologist, 63(6), 503-517. https://doi.org/10.1037/0003-066x.63.6.503

Nasir, M., and Iqbal, S. (2019). Academic self efficacy as a predictor of academic achievement of students in pre service teacher training programs. Bulletin of Education and Research, 41(1), 33-42.

Owen, S. V., and Froman, R. D. (1988). Development of a college academic self-efficacy scale. Paper presented at the annual meeting of the national council on measurement in education. New Orleans. LA.

Pehlevan, Z., Mustu, E., and Çepikkurt, F. (2017). Examination of occupational anxiety levels and academic self-efficacy of physical education teacher candidates. Universal Journal of Educational Research, 5(11), 1926-1939.

Saeed, W., and Ahmad, R. (2020). Association of demographic characteristics, emotional intelligence and academic self-efficacy among undergraduate students. Journal of Pakistan Medical Association, 70(3), 457-460.

Sert, M. and Traş, Z. (2017). Ergenlerin Duygusal Zekâ Düzeyleri İeÖz-Yeterlik Algıları Arasındaki İlişkinin İncelenmesi. Manas Sosyal Araştırmalar Dergisi, 8(1), 12051220.

Schunk, D. H. (1991). Self-efficacy and academic motivation. Educational Psychologist, 26, 207-231.

Schunk, D. H., and Pajares, F. (2002). The development of academic self-efficacy. In Development of achievement motivation (pp. 15-31). Academic Press.

Şenel, E., and Tamer, K. (2018). Evaluation of some factors affecting self-efficacy beliefs of students studying in teacher education departments Öğretmenlik bölümlerinde öğrenim gören öğrencilerin öz yeterlik inançlarını etkileyen bazı faktörlerin değerlendirilmesi. Journal of Human Sciences, 15(3), 1717-1726.

Taşdemir, C. (2019). An investigation of academic self-efficacy perceptions of primary mathematics teacher candidates. Higher Education Studies, 9(2), 72-80.

Titrek, O., Çetin, C., Kaymak, E., and Kaşıkçı, M. M. (2018). Academic motivation and academic self-efficacy of prospective teachers. Journal of Education and Training Studies, 6(11a), 77-87. 
Türkekul, K., and Sarıkabak, M. (2019). Beden Eğitimi ve Spor Öğretmeni Adaylarinin duygusal zeka düzeyleri ve akademik öz yeterlikleri arasındaki ilişkinin incelenmesi. Uluslararası Güncel Ĕ̈itim Araștrmalanı Dergisi, 5(1), 52-69.

Kaynakça Bilgisi / Citation Information

Baydar, A. (2021). Association between emotional intelligence and academic self-efficacy of preservice primary teachers. OPUS-International Journal of Society Researches, 17(36), 2370-2382. DOI: 10.26466/opus.837349 